\title{
Natural cytotoxicity of tilapia leucocytes
}

\author{
M. Faisal ${ }^{1,4, *}$, Iman I. Ahmed ${ }^{2,4}$, Gabriele Peters ${ }^{3}$, E. L. Cooper ${ }^{2}$ \\ ${ }^{1}$ Department of Microbiology and Immunology, ${ }^{2}$ Department of Anatomy and Cell Biology, University of California, \\ Los Angeles, California 90024, USA \\ ${ }^{3}$ Institut für Hydrobiologie und Fischereiwissenschaft, University of Hamburg, Federal Republic of Germany \\ ${ }^{4}$ Faculty of Veterinary Medicine, University of Alexandria, Egypt
}

\begin{abstract}
We have demonstrated the presence of natural cytotoxic cells (NCC) against the murine cell line YAC-1 in tilapia (Tlapia mossambica $\times$ T honorum) fish. NCC-activities were observed in the anterior kidney, trunk kidney, spleen and peripheral blood. The highest cytotoxicity was found in the anterior kidney while the lowest was in the blood. Macrophages form over $70 \%$ of conjugate forming cells (CFC) in anterior and trunk kidney as well as spleen, while lymphocytes represent the main CFC in peripheral blood. The optimum temperature for $\mathrm{NCC}$ activity was $28^{\circ} \mathrm{C}$. Maximum ${ }^{51} \mathrm{Chromium}$ release from labelied targets was between 3 and $6 \mathrm{~h}$ of incubation with anterior kidney leucocytes at $28^{\circ} \mathrm{C}$. We also have evidence for the production of cytotoxic factors(s) upon coincubation with YAC-1 cells. NCC diminishes as the fish mature and age.
\end{abstract}

\section{INTRODUCTION}

Susceptibility to disease-causing microorganisms and the development of neoplasms are controlled by the immune system. Among mammalian immune cells there is a subpopulation called natural killer (NK) cells which causes spontaneous lysis of different leukemic cell lines in the absence of antibodies and without any previous exposure to the target cells (Lanier \& Phillips 1986). These lymphoid cells are thought to play a vital role in immunosurveillance, resistance to infections, and the regulation of hemopoiesis (Lotzova 1986). Teleostean leucocytes also possess the ability to lyse, in vitro, a variety of mammalian and piscine tumor cell lines (Hinuma et al. 1980, Moody et al. 1985). Evans et al. (1984a, b, c), as well as Carlson et al. (1985), reported a number of similarities between cytotoxic cells of human and channel catfish Ictalurus punctatus. The mechanism by which piscine natural cytotoxic cells (NCC) recognize and kill target cells is still unknown. In the present study we examined the nature of NCC of an economically important warmwater teleost, tilapia (Pisces: Cichlidae), their distribution in the hemopoietic tissues, the optimum temperature and kinetics of their cytotoxicity as well as how these values and the

\footnotetext{
- Present address: Virginia Institute of Marine Science, School of Marine Science, The College of William and Mary, Gloucester Point, Virginia 23062, USA
}

distribution of the NCC may be altered as fish age. We also presented evidence that tilapia NCC can produce cytotoxic factor(s).

\section{MATERIALS AND METHODS}

Fish. Hybrids of Tilapia mossambica $\times T$. honorum of both sexes were obtained from the Pacific Aqua Farms, Niland, California, USA. The fish were maintained for at least $10 \mathrm{~d}$ in 150-l glass aquaria at a temperature of $18^{\circ} \mathrm{C} \pm 2^{\circ}$. Fish were divided into 5 groups according to their ages: 2, 4, 6, 12 and $18 \mathrm{mo}$. Except for the aging experiments, 6 mo old fish $(18.5 \pm 4 \mathrm{~cm}, 220 \pm 14 \mathrm{~g})$ were used throughout this study.

Media. All cell cultures were performed in a complete medium (CM) that consisted of RPMI-1640 (Flow Laboratories, Rockville, Maryland, USA) $10 \%$ heatinactivated fetal calf serum (FCS) and antibiotics (50 units penicillin and $50 \mu \mathrm{g}$ streptomycin per $\mathrm{ml}$ ). Fish leucocytes were washed in Hank's balanced salt solution (HBSS) before reacting them with tumor targets.

Cell preparation. Fish were anesthetized with MS222 (200 $\mathrm{mg} \mathrm{l}^{-1}$ ) (Sandoz, Switzerland) and heparinized blood was collected from the caudal vein. The anterior kidney, trunk kidney and spleen were removed and cell suspensions prepared by gently pressing them through 80-gauge mesh stainless steel sieves in petri dishes containing $3 \mathrm{ml}$ of RPMI-1640 medium. Cells 
were washed 3 times with HBSS and resuspended in CM. Peripheral blood (2 ml) was diluted 3 times with HBSS, overlaid on Histopaque 1077 (Sigma, Missouri, USA) and centrifuged for $20 \mathrm{~min}$ at $500 \times \mathrm{g}$ (room temperature). Cells at the interface with the histopaque layer were collected, diluted 1:5 in HBSS and centrifuged $(250 \times g, 5 \mathrm{~min})$. The pelleted cells were resuspended in $10 \mathrm{ml}$ RPMI ( $5 \% \mathrm{FCS}$ ).

Cell counts were performed with the aid of a Neubauer chamber hemacytometer. Cell viability was determined using trypan blue (2\% w/v) exclusion staining. For examination of the morphological properties of the isolated cells, $0.1 \mathrm{ml}$ of the cell suspension $\left(3 \times 10^{6}\right.$ cells $\left.\mathrm{ml}^{-1}\right)$ was added to cytocentrifuge cups (Shandon, England) prewetted with $0.1 \mathrm{ml}$ phosphate buffer saline containing $1 \%(\mathrm{w} / \mathrm{v})$ bovine serum aloumin. Following centrifugation $(600 \times g, 5 \mathrm{~min})$, slides were prepared and then stained with Giemsa's stain

Target cells. A virus-induced lymphoma cell line, YAC-1 (Kiessling et al. 1975) of A/Sn mouse origin, was maintained in suspension culture at $37^{\circ} \mathrm{C}$ in $\mathrm{CM}$ and used as targets for fish effector cytotoxic cells.

${ }^{51} \mathrm{Cr}$ release assay. YAC-1 cells $\left(5 \times 10^{6}\right)$ suspended in $0.3 \mathrm{ml}$ of $\mathrm{CM}$ were incubated with $100 \mu \mathrm{Ci}$ of $\mathrm{NA}_{2}{ }^{51} \mathrm{CrO}_{4}$ (New England Nuclear, Boston, Massachusetts) for 1 h at $37^{\circ} \mathrm{C}$. Following 3 washings with $\mathrm{CM}$, the chromated cells were diluted to $1 \times 10^{5}$ cells $\mathrm{ml}^{-1}$, and $10^{4}$ cells delivered to each well of a 96 -well round bottom microtiter plate (Nurclon, Denmark). Fish effector cells suspended in CM were then added in 100 ul volumes at effector-to-target cells ratios of 100 , 50 and 25. Following a $4 \mathrm{~h}$ incubation at $22^{\circ} \mathrm{C}$ the plates were centrifuged $(250 \times \mathrm{g}, 5 \mathrm{~min})$, and $0.1 \mathrm{ml}$ of collected supernatant from each well was counted in a Beckman gamma counter. Percent specific chromium release was calculated as follows:

$$
\begin{gathered}
\% \text { specific release }= \\
\frac{(\text { test release })-(\text { spont. release })}{(\text { max release })-(\text { spont. release })} \times 100 \%
\end{gathered}
$$

Maximum release (max) was measured by adding $0.1 \mathrm{ml}$ Triton X-100 (Sigma) to the designated wells while spontaneous release (spont.) was measured by adding $0.1 \mathrm{ml}$ medium to the target cell. For purpose of comparison, the data were transformed with the aid of a computerized nonlinear equation program described by Pross et al. (1981) into lytic units $\left(\mathrm{LU}_{40}\right)$ per $10^{7}$ effector cells. One lytic unit represents the number of effector cells necessary for $40 \%$ specific lysis of 10000 chromated YAC-1 cells.

Conjugate formation. Effector cells $\left(1 \times 10^{4}\right)$ were incubated with $1 \times 10^{5}$ YAC-1 target cells in $1 \mathrm{ml}$ of $\mathrm{CM}$ in $12 \times 75 \mathrm{~mm}$ glass tubes, sedimented by centrifugation at $200 \times g$ for $5 \mathrm{~min}$ and incubated for $1 \mathrm{~h}$ at $4{ }^{\circ} \mathrm{C}$.
Pellets were resuspended, and cytocentrifuged preparations were stained with Giemsa. An effector cell that has intimate contact with a target cell at the outer cell surface was considered a conjugate forming cell. Percentage of conjugate forming cells (CFCs) was determined by counting 200 leucocytes (bound and free) in triplicate samples.

Production of cytotoxic factors by tilapia cytotoxic cells. According to procedures described by Wright and Bonavida (1983), effector cells were co-cultured with YAC-1 cells at a ratio of 25:1 (effector:target). The final concentration of effector cells was $5 \times 10^{6}$ cells $\mathrm{ml}^{-1}$. Cultures were initiated in a total volume of 1 to $3 \mathrm{ml}$ in $17 \times 100 \mathrm{~mm}$ tissue culture tubes (Falcon, Lancaster, Pennsylvania, USA). Controls were YAC-1 stimulator cells cultured in the absence of effector cells and effector cells cultured in the absence of target cells. After $24 \mathrm{~h}$ incubation $\left(28{ }^{\circ} \mathrm{C}\right.$ in $\left.5 \% \mathrm{CO}_{2}\right)$ the cell-free supernatants were harvested and stored aliquoted at $-20^{\circ} \mathrm{C}$ until assaying or at $4{ }^{\circ} \mathrm{C}$ for use within $24 \mathrm{~h}$.

Fifty microliters of chromated target cell suspension $\left(2 \times 10^{5}\right.$ cells $\left.\mathrm{ml}^{-1}\right)$ were added to each well of a 96 well $U$ bottom microtiter plate. Different volumes (100, $50,25 \mu \mathrm{l})$ of cell-free supernatants to be tested for the cytotoxic factor were added to each well. The volume was adjusted to $0.2 \mathrm{ml}$ by adding culture medium. The final concentration of bovine serum was $5 \%$. Wells for spontaneous ${ }^{51} \mathrm{Cr}$ release contained target cells plus $150 \mu \mathrm{l}$ RPMI while those for total release contained $100 \mu \mathrm{l}$ Triton X-100 and $50 \mu \mathrm{l}$ RPMI. After $20 \mathrm{~h}$ incubation at $37^{\circ} \mathrm{C}$ at $5 \% \mathrm{CO}_{2}$ tension, the ${ }^{51} \mathrm{Cr}$ release was counted and percentage of cytotoxicity calculated as mentioned before.

Statistical analyses. Standard deviation of the means were calculated and comparisons were made using the Students $t$-test.

\section{RESULTS}

\section{Distribution of natural cytotoxic cells (NCCs) in different tissues of tilapia}

Leucocytes from the anterior kidney, trunk kidney, spleen and peripheral blood were tested for their cytolytic activity against YAC-1 cells. As shown in Fig. 1, anterior kidney leucocytes (AKLs) possess the greatest cytotoxic activity $\left(7.6 \pm 0.7\right.$ lytic unit $\left.40, \mathrm{LU}_{40}\right)$, followed by splenic $\left(2.9 \pm 0.4 \mathrm{LU}_{40}\right)$ and then trunk kidney $\left(1.4 \pm 0.5 \mathrm{LU}_{40}\right)$ leucocytes. Peripheral blood leucocytes (PBLs) showed the lowest amount of cytotoxicity $\left(0.55 \pm 0.45 \mathrm{LU}_{40}\right)$. Similar results were calculated for the percentage of leucocytes forming conjugates with YAC-1 cells. A relatively high number $(59.2 \%)$ of anterior kidney cells formed conjugates. In 
spite of the low cytotoxicity of trunk kidney (TKLs) and splenic (SLs) leucocytes, more than $40 \%$ of these cells formed conjugates. PBLs showed a much lower tendency $(20 \% \pm 5)$ than other leucocytes examined.

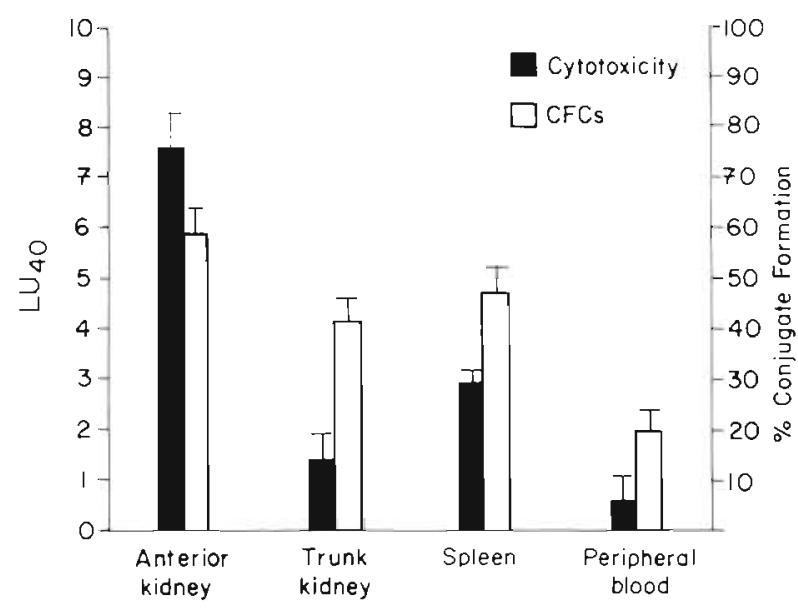

Fig. 1 Nonspecific cytotoxic cell activity expressed as lytic units $\left(\mathrm{LU}_{40}\right)$ and \% of conjugate forming cells (CFCs) in different tilapia hemopoietic tissues and peripheral blood. Data expressed as means \pm SD obtained from 15 fish

Three leucocytic types were recognized that bind to target cells, namely lymphocytes, monocytes/macrophages and polymorphonuclear (PMNs or ProPMNs). Interestingly, there was a clear variation in the type of conjugate-forming cell (CFC) among the tissues examined (Fig. 2). Macrophages formed most of the conjugates (65 to $75 \%$ ) among AKLs, TKLs and SLs, while among PBLs, monocytes formed as low as $10.6 \%$ of CFCs. On the contrary, lymphocytes as well as other lymphoid cells (Fig. 3) formed more than $80 \%$ of CFCs among PBLs and less than $20 \%$ among AKLs, TKLs and SLs. Polymorphonuclear cells and ProPMNs showed a minimal value (5 to $10 \%$ ) within the CFCs in all tissues examined.

\section{Effect of incubation temperature on NCC}

Anterior kidney effector cells were tested for their cytotoxic activities at four different temperatures: 4,18 , 28 and $37^{\circ} \mathrm{C}$ (Fig. 4). At $28^{\circ} \mathrm{C}$ the cytotoxic activity of tilapia effector cells was higher $(\mathrm{p} \leq 0.001)$ than other incubation temperatures tested. Minimal killing activity was observed at $4{ }^{\circ} \mathrm{C}$. On the other hand, binding to target cells showed temperature-independence to the degree that no statistically significant differences could be observed in the \% of CFCs at the different temperatures.

\section{Kinetics of cytotoxicity}

Anterior kidney cells were tested at different time intervals of co-culture with chromated target cells to determine the optimum time required by tilapia effectors for lysis of YAC-1 cells. As shown in Fig. 5, NCCactivity was detected as early as $0.5 \mathrm{~h}$ postincubation (p.i.), then increased gradually forming a plateau between 3 and 6 h p.i. Afterwards, specific lysis decreased gradually, mainly due to higher levels of spontaneous release of ${ }^{51} \mathrm{Cr}$ from target cells. In contrast, percentages of conjugate forming cells reached maximum levels as early as $1 \mathrm{~h}$ and then began to decrease after 3 h (Fig. 5).

\section{Production of the cytotoxic factor}

Tilapia AKLs from 6 individual fish were tested for their ability to produce cytotoxic factors (CF) when cocultured with YAC-1 cells. The data obtained gave clear evidence of the production of a soluble factor(s) that could induce lysis of YAC-1 cells in the absence of effectors. Supernatants of cultured unstimulated effectors or targets showed negligible cytotoxic activity (Table 1).
Fig. 2. Types of conjugate forming cells (CFCs) in tilapia hemopoietic tissues and peripheral blood. PMN = polymorphonuclear cells. Data expressed as means \pm SD from 10 fish

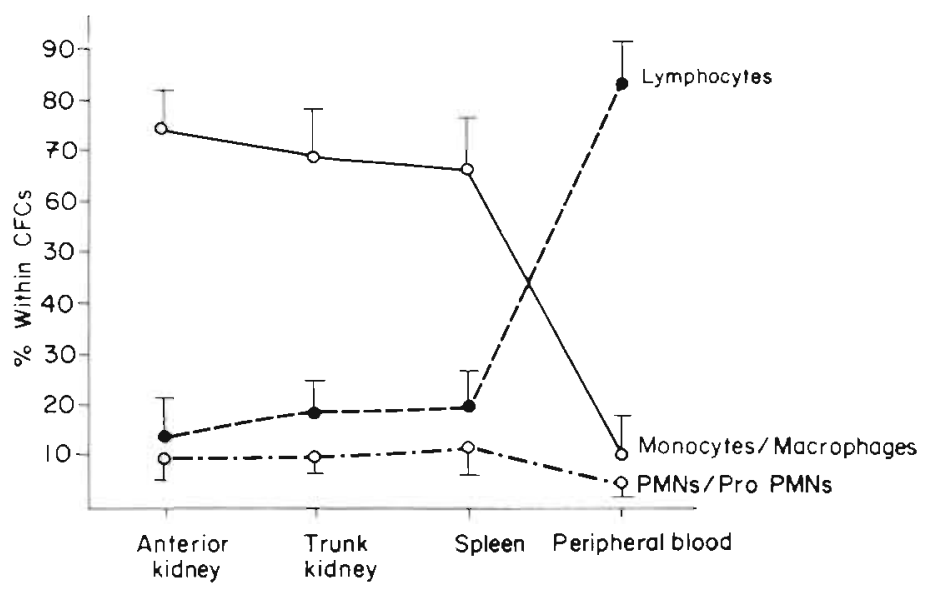




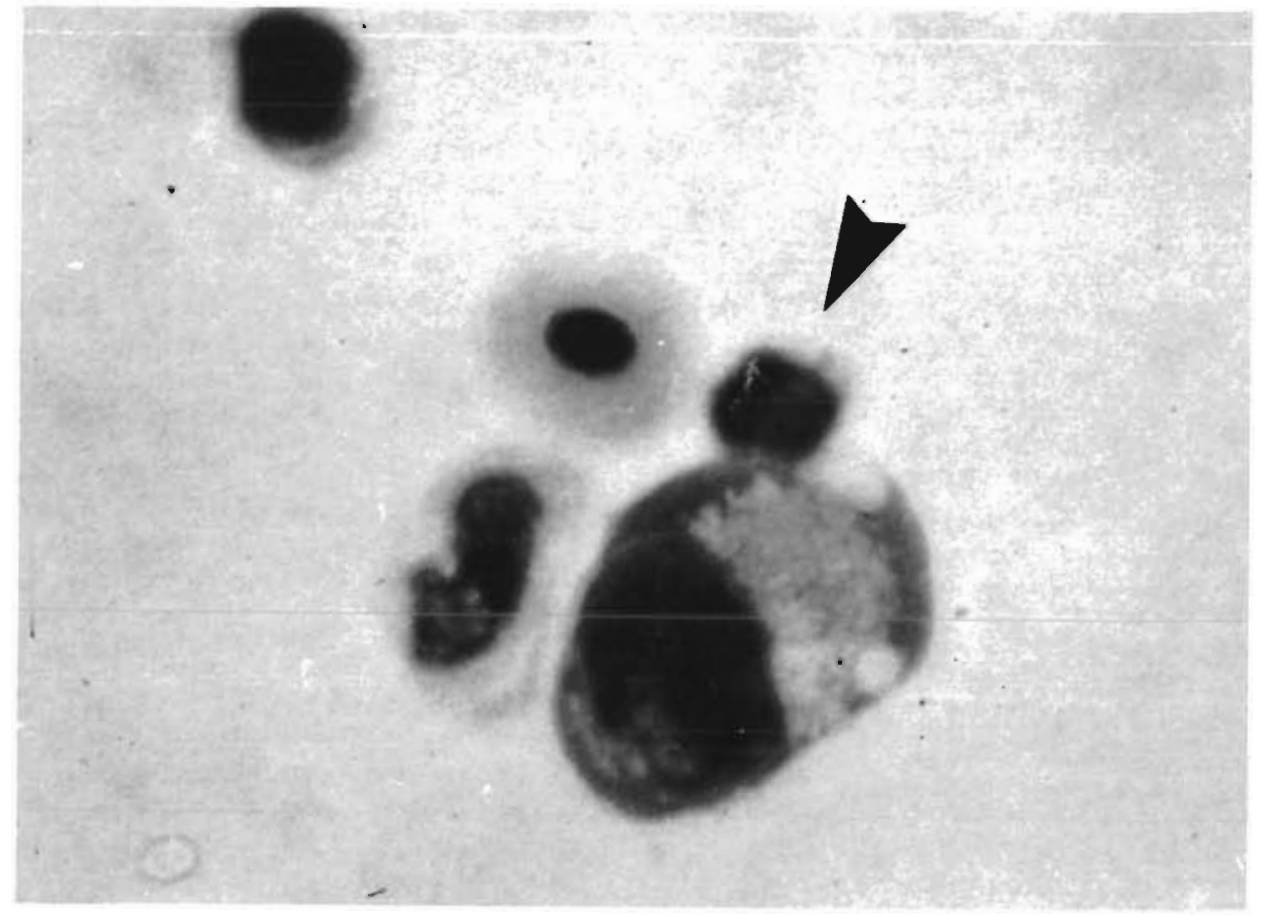

Fig. 3. A lymphocyte (arrow) forming conjugate with YAC-1 cells; stained with Giesma $(\times 1000)$

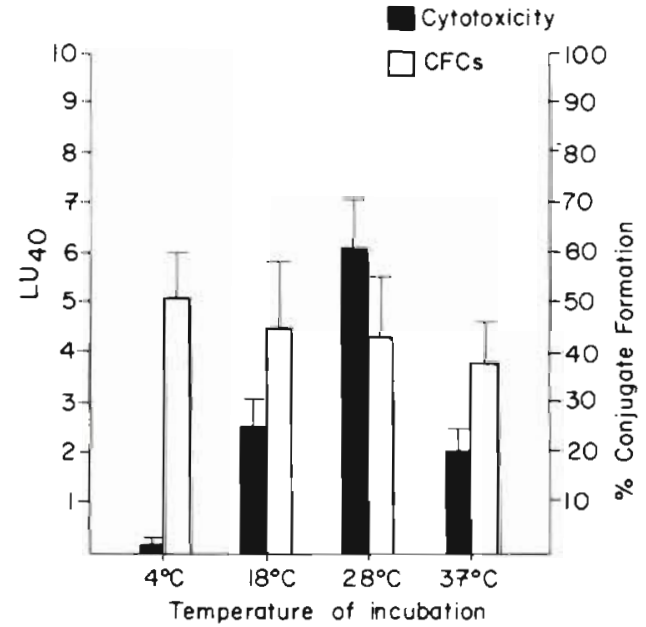

Fig. 4. Effect of temperature on cytotoxicity lexpressed as $\mathrm{LU}_{40}$ ) and conjugate formation (CF) of tilapia anterior kidney effectors with YAC-1 cell lines. Data expressed as means \pm $\mathrm{SD}$ from 15 fish

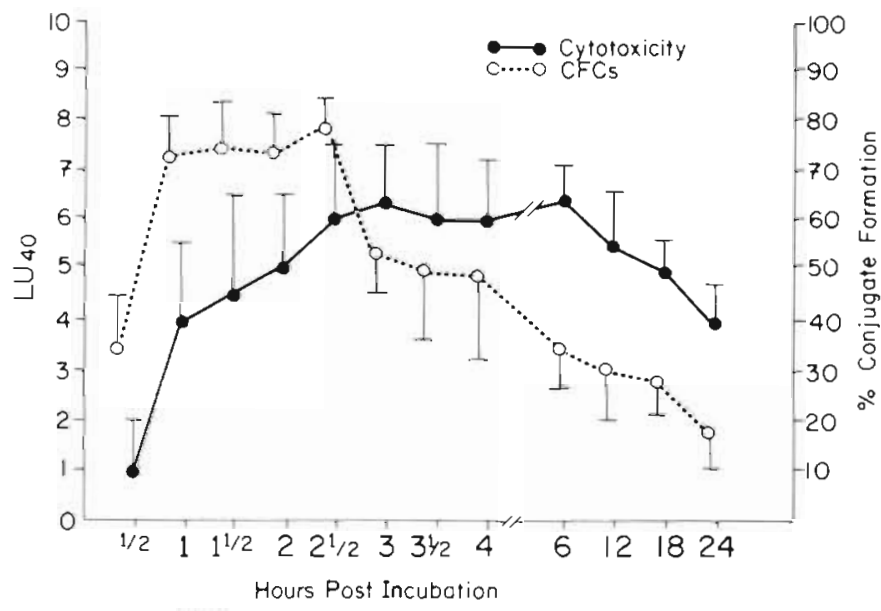

Fig. 5. Kinetics of cytotoxicity (expressed as $L_{40}$ ) and conjugate formation (CF) of tilapia anterior kidney cells with YAC-1 at $28{ }^{\circ} \mathrm{C}$. Data expressed as means $\pm \mathrm{SD}$ of 15 experiments. In each experiment AKLs were obtained from 3 individual fish and pooled

\section{DISCUSSION}

Obviously fish continue to survive in hostile environments replete with disease-causing microorganisms. This is due to an effective defense system. To test one component of the immune system, we analyzed natural cytotoxic leucocytes (NCC) in tilapia and found that those from anterior kidney showed the highest activity when compared with others derived from spleen, trunk kidney or peripheral blood. Our findings on NCC are 
Table 1. Evidence for production of soluble cytotoxic factor(s) by tilapia anterior kidney leucocytes. Data expressed as means \pm SD of 6 individual fish. Culture: cell tree supernatant of culture; Quantity: quantity added to chromated target cells;

${ }^{51} \mathrm{Cr}$ : percent specific ${ }^{51} \mathrm{Cr}$-release

\begin{tabular}{|lrc|}
\hline Culture & Quantity $(\mu \mathrm{l})$ & ${ }^{51} \mathrm{Cr}$ \\
\hline Effector cells co-cultured & 100 & $22.5 \pm 1.0$ \\
with YAC-1 & 50 & $12.6 \pm 1.4$ \\
& 25 & $8.0 \pm 0.7$ \\
Effector cells only & 100 & $1.5 \pm 0.9$ \\
& 50 & 0 \\
YAC-1 cells only & 25 & 0 \\
& 100 & $0.6 \pm 0.5$ \\
& 50 & 0 \\
& 25 & 0 \\
\hline
\end{tabular}

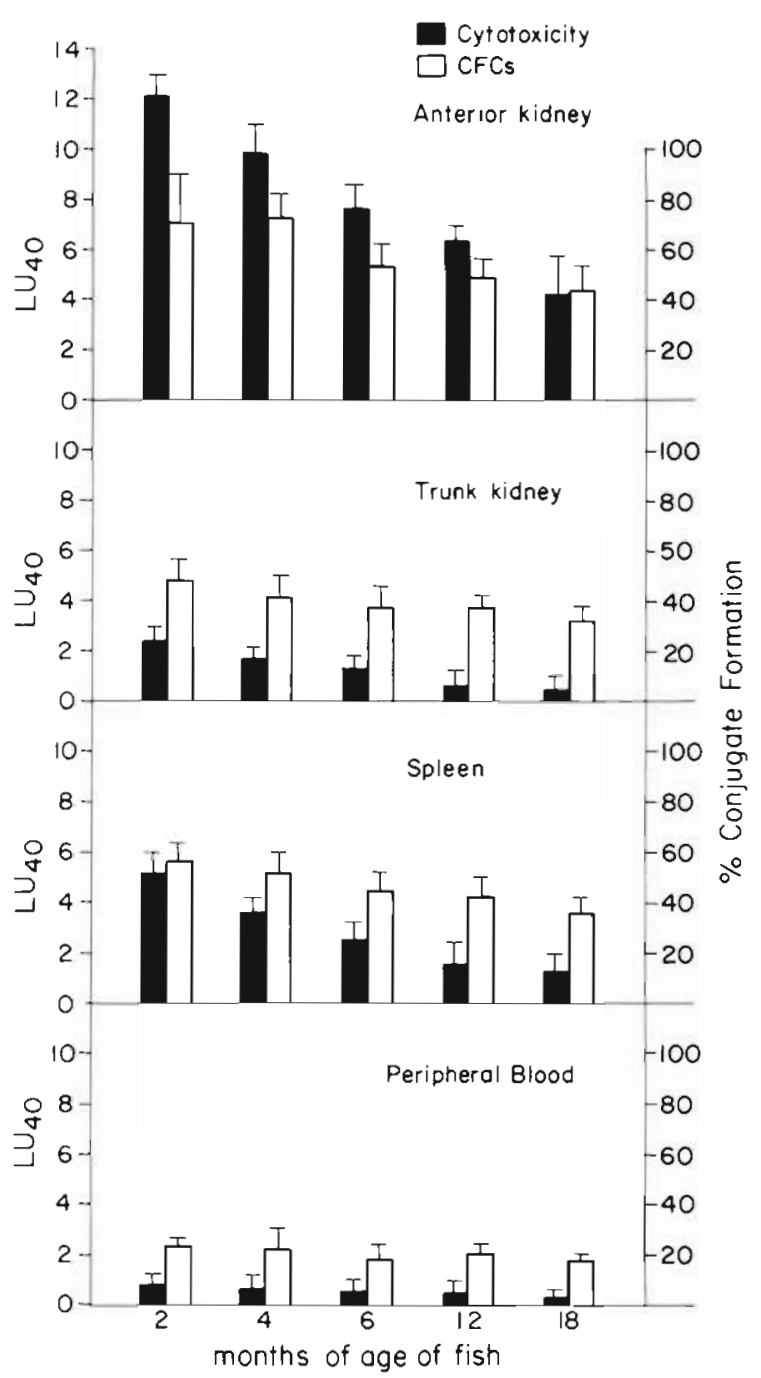

Fig. 6. Effect of fish age on cytotoxicity (expressed as $\mathrm{LU}_{40}$ ) and conjugate formation (CCF) in different hemopoietic tissues and peripheral blood. Data are means $\pm \mathrm{SD}$ similar to others using different fish species. In common carp Cyprinus carpio (Hinuma et al. 1980), and in channel catfish Ictalurus punctatus (Evans et al. 1984 b), anterior kidney showed the greatest cell lysis. Splenic leucocytes had moderate to high cytotoxicity in Atlantic salmon Salmo salar, common carp and channel catfish, but no cytotoxic activity was observed using leucocytes from spleen of rainbow trout Salmo gairdneri (Hinuma et al. 1980, Evans et al. 1984b, Hayden \& Laux 1985, Moody et al. 1985). This variation extends also to PBLs which showed low cytotoxicity in 1 . punctatus but consistently high lytic activity in Salmo gairdneri (Evans et al. 1984b. Hayden \& Laux 1985). Apparently the pattern of NCC distribution differs among the species.

In the present study, tilapia cells capable of forming conjugates were identified as monocytes/macrophages, as lymphocytes or PMNs. Using purified preparations Evans et al. (1984c) described channel catfish conjugate forming cells as monocyte-like cells which possessed reniform nuclei and a low nucleus/cytoplasm ratio. However, based on size discrimination by flow cytometry techniques, Evans et al. (1987) described 4 cell populations in the anterior kidney and 3 in the spleen which could recognize and bind to the target cells, NC-37. Our data agree partially with those of the previous authors since macrophages formed more than $70 \%$ of CFCs in the anterior kidney and spleen. However, it is clear from our study, that recognition and binding to tumor target cells is a property shared by a variety of other cells e.g. PMNs and lymphoid cells.

The effects of different incubation temperatures during the assay were analysed. Optimal cytotoxicity apparently occurs at $28{ }^{\circ} \mathrm{C}$ but at higher and lower temperatures, cytotoxicity decreased. Other studies revealed different results for other fish species, e.g. optimum temperature for channel catfish is 16 to $25^{\circ} \mathrm{C}$ (Evans et al. $1984 \mathrm{C}$ ), $25^{\circ} \mathrm{C}$ for common carp (Hinuma et al. 1980) and $20^{\circ} \mathrm{C}$ for Atlantic salmon (Moody et al. 1985). In this respect, optimum temperature for tilapia lies within the range for other warmwater fish e.g. Cyprinus carpio. The independence of conjugate formation of tilapia leucocytes from temperature was an interesting observation but remains unconfirmed in general for fish since no other studies aimed at following temperature kinetics of conjugate formation in other fish species are known.

Maximum levels of killing activities of tilapia NCC were observed between 3 and $6 \mathrm{~h}$ of incubation at $28^{\circ} \mathrm{C}$. Previous reports on other teleost species showed optimal NCC activity at $8 \mathrm{~h}$ at a temperature of $20^{\circ} \mathrm{C}$ for salmonids (Moody et al. 1985) and at $6 \mathrm{~h}$ at $28^{\circ} \mathrm{C}$ for the channel catfish (Evans et al. 1984b). This variability may result from an adaptation of fish to different temperatures. Conjugate formation was observed at a high 
level as early as $1 \mathrm{~h}$ but it dropped at $3 \mathrm{~h}$ postincubation, i.e., the time at which cell lysis began. Lysis under these conditions might represent a logical sequence since recognition and binding precedes the cytolytic process. The data presented in Table 1 suggest a possible role of soluble mediator(s) in tilapia NCC-mediated cytotoxicity system. Preincubation with YAC-1 appeared, however, essential for elaboration of this mediator. This so called stimulus-secretion model has been proposed for the lytic mechanisms of mammalian NK and cytotoxic T lymphocytes (Lotzova 1986). It was also reported that lymphokines like IL-2 and interferons enhance cytotoxic activity of lymphocytes via augmenting the cytotoxic factor production (Wright \& Bonavida 1983). The nature of this factor(s) in piscine $\mathrm{NCC}$ and the role of different cytokines in modulating $i t$, is currently under investigation.

A significant drop in binding and cytotoxic activity of tilapia effectors was clear when the values of 2-mo old fish were compared with those that are 18-mo. This may have an effect on the resistance of fish to pathogens and neoplasms. Similar findings were reported on rats and mice but not humans (Ortaldo \& Herberman 1984). The effect of age on the immune parameters should be considered in future experimental planning.

Acknowledgements. The authors express appreciation to $\mathrm{Mr}$ William Engler, Pacific Aquafarm, who kindly provided the fish used in this study. The Binational Fulbright Commission, Cairo, Egypt provided financial assistance for $M$ Faisal

\section{LITERATURE CITED}

Carlson, R. L., Evans, D. L., Graves, S. S. (1985). Nonspecific cytotoxic cells in fish (Ictalurus punctatus). V Metabolic requirements of lysis. Devl comp. Immun., N. Y 9:271-280 Evans, D. L., Carlson, R. L., Graves, S. S., Hogan, K. T (1984a).

Responsible Subject Editor: Professor O. Kinne, Oldendorf/ Luhe, F.R. Germany
Nonspecific cytotoxic cells in fish (Ictalurus punctatus). IV Target cell binding and recycling capacity. Devl comp. Immun., N. Y. 8: 823-833

Evans, D. L., Graves, S. S., Cobb, D., Dawe, D. L. (1984b). Nonspecific cytotoxic cells in fish (Ictalurus punctatus). II Parameters of target cell lysis and specificity. Devl comp. Immun., N. Y 8: 303-312

Evans, D. L., Hogan, K. T., Graves, S. S., Carlson, R. L., Floyd, E. Dawe, D. L. (1984c). Nonspecific cytotoxic cells in fish (Ictalurus punctatus). III. Biophysical and biochemical properties affecting cytolysis. Devl comp. Immun., N. Y. 8: $599-610$

Evans, D. L., Smith, E. E., Brown, F. E. (1987). Nonspecific cytotoxic cells in fish (Ictalurus punctatus). VI. Flow cytometric analysis. Devl comp. Immun., N. Y 8: 95-104

Hayden, B. J., Laux, D. C. (1985). Cell-mediated lysis of murine target cells by nonimmune salmonid lymphoid preparations. Devl comp. Immun., N. Y. 9: 627-639

Hinuma, S., Abo, T., Kumagga, K., Hata, M (1980) The potent activity of freshwater fish kidney cells in cell-killing. I Characterization and species-distribution of cytotoxicity Devl comp. Immun., N. Y 4: 653-666

Kiessling, R., Klein, E., Wigzell, H. (1975). Cytotoxic cells with specificity for mouse Maloney leukemia cells. Specificity and distribution according to genotype. Eur. J. Immunol. 5: 112-118

Lanier, L. L., Phillips, J. H. (1986). Evidence for three types of human cytotoxic lymphocyte. Immunol. Today 7. 132-134

Lotzova, E. (1986). NK cell role in regulation of the growth and functions of hemopoietic and lymphoid cells. In: Lotzova, E., Herberman, R. B. (eds.) Immunobiology of Natural Killer Cells, vol. 2. CRC Press, Boca Raton, 89-105

Moody, C. E., Serreze, D. V., Reno, P. W (1985). Non-specific cytotoxic activity ol teleost leukocytes. Devl comp. Immun., N. Y 9:51-64

Ortaldo, J. R., Herberman, R. B. (1984). Heterogeneity of natural killer cells. A. Rev. Immunol. 2: 359-394

Pross, H. F., Baines, M. (i., Rubin, P., Shragge, P., Patterson. M. S. (1981). Spontaneous human lymphocyte-mediated cytotoxicity against tumor target cells. IC. The quantitation of natural killer cell activity. J. Clin. Immunol. 1: 51-63

Wright, S. C., Bonavida, B. (1983). Studies on the mechanism of natural killer cytotoxicity. III. Activation of NK cells by interferon augments the lytic activity of released natural killer cytotoxic factors (NKCF). J. Immunol. 130: 2960-2964

Manuscript first received: February 3, 1989

Revised version accepted: July 25, 1989 